\title{
Divisions of labor and the relations among them: some thoughts on "uneven and combined" theory and politics
}

\author{
Sharryn Kasmir ${ }^{1}$ (D)
}

Published online: 11 September 2020

(C) Springer Nature B.V. 2020

In mid-May 2020, I attended a panel discussion on the theme of "Workers struggles and Covid-19." The virtual event was convened by a Pennsylvania coalition launched earlier this year. The group is spearheading a statewide effort to elect progressive local- and state-level candidates and to defeat Donald Trump. Pennsylvania helped elect Trump four years ago, and it is now a key battleground state in 2020. The coalition's regional chapters organize varied, diverse groups of people across nine counties - urban, suburban, or rural places that are populated largely by people of color or largely by white people; who are poor, working, or middle class; and who, in greater or lesser numbers, are immigrants of mixed legal status. My ethnographic fieldwork in Pennsylvania brought me to the event. I am researching political organizing and social change in the majority Latinx, heavily immigrant, rustbelt city of Reading and the surrounding wealthier, largely white, suburban, and rural Berks County. ${ }^{1}$

The invited panelists addressed the topic of "essential workers." One guest speaker is the executive director of a national non-profit that advocates for restaurant workers. Covid-19 put out of work vast numbers of restaurant servers, yet many are barred from unemployment benefits because their $\$ 2.83$ hourly sub-minimum-wage (tipped service work is exempted from federal minimum wage regulation) means they earned too little to qualify for benefits. The panelist rejected the designation "essential" for the way it rendered other labor invisible, devalued, and marginal, and because it replayed the New Deal segmentation of the US working class into differently recognized and valued parts. The 1938 Fair Labor Standards Act instituted a national wage floor but excluded tipped, domestic, and farm work. This maneuver brought the racial legacies of slavery, sharecropping, and Black women's domestic service squarely into the New Deal (Mullings 1986, 1997.) The state delineated "the working class" in ways that had long-term economic, social, and political consequences. The particular, Fordist working class that was then "made" was a racial (disproportionately white) and gendered (largely male) formation. Responding to the needs of displaced restaurant servers, the non-profit solicited donations through a GoFundMe drive. The effort raised

\footnotetext{
${ }^{1}$ I am conducting fieldwork as a member of the project "Frontlines: Class, Value and Social Transformation in 21st Century Capitalism," with funds from University of Bergen, Bergen Foundation, and the Government of Norway. A Faculty Research and Development grant from Hofstra University also helped fund the research.
}

Sharryn Kasmir anthsmk@hofstra.edu 
$\$ 21$ million, to be dispersed through cash payouts. As a result, the organization gained 170,000 new contacts, whom it will mobilize to lobby legislators to increase the federal minimum wage to $\$ 15$ per hour for all categories of workers.

A second panelist, a labor organizer, to the contrary saw utility in the designation "essential work." He argued that it provided a unique opportunity to plan strategic and nimble labor actions and to orient towards power. Job actions at choke holds (strategic sectoral or transport nodes) could stall production and distribution and interrupt supply chains. Essential workers in transport, food, energy, or other critical sectors are located at pivotal points along those chains. Waves of strikes could inflict serious economic damage, and they could assert working-class power against capital. A recent string of wildcat strikes that shut down fruit and vegetable warehouses in Yakima County, Washington, showed the way. Hundreds of workers across multiple businesses struck for hazard pay of an additional \$2 per hour and for safer working conditions in the crowded, concrete packing houses. Yakima reported the highest Covid infection rate on the west coast when the walkout happened. The farmworkers' union Familias Unidas por la Justicia represented the workers and reported that the strikes were led by women and were multiracial and multigenerational (Bacon 2020.)

The job actions in Yakima targeted food distribution at a time when the global supply chain proved vulnerable. Both policy experts and consumers witnessed shortages of medical equipment and feared that food and basic consumer goods would go missing from store shelves. The labor organizer judged that there was a small window of opportunity, perhaps only weeks, to exploit that vulnerability and to seize the day. US labor institutions have been in decline and on the defensive for decades, he reflected; hence, unions have not been innovative in their tactics or far-reaching in their vision. A choke hold initiative, at this unique moment when supply chains were already imperiled, could be a seed for a resurgence of organized labor. The classification essential labor was important because it pinpointed a target for high-impact action, because it had the potential to do real harm to individual owners and to the national economy, and because it could be used to summon a strategic sector of the working class to action.

I recount the speakers' disagreement here to weigh insights from the anthropology of labor and to examine the uneven ground of twenty-first-century capitalism in the USA, the heterogeneity of the US working class, and the varied organizational forms and tactics on the left. I use the theory of uneven and combined development to illuminate this crisis moment and to help us think our way out. This is a period when processes of differentiation are laid bare and underlying social relations are, perhaps, more clearly articulated and leveraged.

\section{Divisions of labor}

The US government response to the Covid pandemic (ineffective, chaotic, and contradictory though it was for safeguarding public health) reorganized labor. Shelter-in-place and stay-athome orders issued by individual states shuttered sectors and workplaces, and designated others essential (health care, energy, child care, agriculture, and food production, transportation, etc.) The emergency federal stimulus package (CARES Act) supplemented state unemployment benefits for some displaced by the Covid shut down. The temporary Pandemic Unemployment Assistance added $\$ 600$ per week to state unemployment checks. Like benefits allocated by individual states, the federal supplement was reserved for workers who could document sufficient income earned on the books, from legally sanctioned employment. Advocates rightly took it as a win that self-employed, gig, and part-time workers were counted 
in; no small effort was required to secure that measure since they had not before been recognized as "employees" before the law. But those without a social security or individual tax identification number, sub-minimum wage earners, and those with irregular work or informal livelihood strategies were counted out.

People of color and immigrants were disproportionately on the front lines and more exposed to Covid. Their higher infection and death rates tell that story in the most brutal terms. Simultaneously, they were less likely to qualify for unemployment assistance from states and the federal government. Amidst these stark inequalities, the practices of categorizing, differentiating, and valuing were on full display. Whereas these processes are typically hidden from view, and the political agency that brings them about is obscured, they are now transpiring in plain sight. The panelists were correct to urge fast action, while the politics of labor are exposed. August Carbonella and I had situations like this in mind when we wrote that labor is a political formation. As state and capital name and categorize; differentiate or unify; and value and devalue human labor, on-theground actors and organizations respond in ways that mold political outcomes. Labor's "social protests and quietude, organizations and cultures reflect multiple engagements with capital and the state, as well as and with other workers locally, regionally, and globally." (Carbonella and Kasmir 2014, p. 7.) Before the (re)making of class - or other forms of identification, organization and power - comes the politics of labor (Carbonella and Kasmir 2014, 2015; Kasmir 2020; Kasmir and Gill 2018.).

From different institutional bases and organizational forms, the panelists on the virtual call enunciated distinct tactics, constituencies, agents, and routes to power. Labor anthropologists have turned our attention to this "problem of heterogeneity" (Smith 2011, 2014). For over forty years, global neoliberal capitalism has disorganized and disempowered working classes via intertwined processes of austerity, deindustrialization, privatization, and capital flight. At the same time, capital accumulation created billions of newly dispossessed people in search of livelihoods, whether waged, irregular, informal, migrant, etc. Our lens has been on the articulation of these world historical processes as they are made manifest, acted upon, and transformed in our fieldwork settings. On the ground, fragmentation testifies to the broad shift in power from workers to capital, and heterogeneity often hobbles common identification, organizing efforts, and solidarity, as much writing on the phenomenon of precarity shows (e.g., Standing 2011.) What theoretical and political tools are required to confront these circumstances?

\section{Uneven and combined}

Some contemporary Marxists turn to Leon Trotsky's uneven and combined development (UCD) to apprehend twenty-first-century capitalism (Trotsky 1960.) ${ }^{2}$ To recall, Trotsky's purpose was to account for the supposed historical anomaly of the Russian Revolutionthat socialist revolution occurred first in semi-feudal Russia rather than in Western European countries with advanced industry, bourgeoisies, and working-class movements. UCD theory begins with the premise that unevenness - differentiation among social relations within and between social formations, and across space, economic sector, and time- is the lifeblood of

\footnotetext{
${ }^{2}$ For example, Dunn and Radice 2006; Davidson 2016; Gill and Kasmir 2016; Kasmir and Gill 2018; Makki 2015; Lem 2016, 2018; Kalb 2018, 2020; Smith 2006; Smith 2016, 2020; Werner 2016.
} 
capital accumulation (Kasmir and Gill 2018.) Walter Rodney's How Europe Underdeveloped Africa (1972), Cedric Robinson's account of racial capitalism (2000), and Silvia Federici's insight that accumulation of labor is "the accumulation of differences" (2004, p. 63) bring unevenness to the forefront of analysis in immensely productive ways. Likewise, unevenness is foundational for how geographers Neil Smith, David Harvey, and Doreen Massey radicalized geography's understanding of space, by theorizing its production by layered, historical processes of capital investment and disinvestment. Importantly for Trotsky, unevenness is also politically momentous.

The notion of "combined" pronounces more clearly the political implications of UCD; however, we are less fluent in the concept and have yet to mine its full creative or intellectual potential. In Trotsky's writing, combined speaks to the presence of so-called advanced (capitalist industrial/urban proletarian) and archaic (semi-feudal/rural peasantry) forms and the revolutionary possibilities that arose from them in early twentieth-century Russia. Currentday UCD theorists salvage the idea from its social evolutionary roots and the teleological presumption of revolution (Kasmir and Gill 2018.). They instead conceptualize "hybrid complexity, structural asymmetry, and contradictory coexistence" (Peck 2019, p. 50) brought together "in contexts where the telos of collective agency is open" (Lem 2018, p. 369; Smith 2016.) Political questions follow from this view of social change: "How and with what effect are these social and political forms hybridized and articulated? [...] What new compositions and configurations might be forged, both in practice and in the political imagination, as the synthesis of multiple determinations, forces, alliance, and determinations?" (Peck 2019, pp. 50-51.)

\section{The relations among them}

Bond, Desai, and Ngwane argue further that we need uneven and combined Marxism in both theory and practice to apprehend actual social relations of contemporary capitalism. They start with the wellspring of protests in South Africa since the 1990s but equally the geographic and political isolation of those movements. As well, they survey an extremely differentiated South African national economy, where construction, finance, and commerce are booming, manufacturing is in decline, and large swaths of the country seem peripheral to the interests of domestic and international capital. The contradictory totality of social relations must be the starting point for the South African left, but "the beginning cannot also be the end." (Bond et al. 2013, p. 235). The endpoint requires more coherence and unity.

Bond, Desai, and Ngwane maintain that enunciating uneven and combined left politics can advance Marxist thought, for it "heightens and encapsulates several otherwise familiar tensions_-urban/rural; worker/poor; local/national/global urban/rural; society/nature; gender and so on-and can show, therefore, perhaps more clearly than in other contexts the essential relations among them" (2013, p. 236.) They believe that this formulation can enrich Marxism with a Southern perspective. It can similarly invigorate anthropology and make our discipline more relevant at this critical time.

When the panelists debated the designation essential workers, they disagreed about identity making, and about where leverage and power lie. They reached different conclusions, promoted distinct actors and tactics, and spoke from different institutional bases, one organized labor; the other the non-profit sector. Their argument manifested the unevenness of capitalism in the USA, the heterogeneity of the working class, and the multiple organizational forms and 
tactics on the left. Rather than assess this state of affairs only as a liability (though surely, it indicates historical disadvantage of the US left), we might instead promote a research program inspired by uneven and combined Marxism. Gavin Smith comments on the difficulty of outlining an effective intellectual role in the context of 21 st societal transformations, when it is not clear who the agents of change are or should be (also Kalb and Mollona 2018). Nor is it obvious how and against whom these actors should channel their energies. Smith writes perceptively, "So if today it is by no means obvious where the seeds of collective will are to be found or through what means some leverage might be achieved, this does not reduce the need for intellectual intervention - rather it impels us to ask what the nature of that intervention might be. For it is not automatically apparent what needs to be taken into account for a useful assessment of the conditions of possibility for the successful intervention of collective will" (Smith 2014, p. 2.)

Anthropologists can gain ground with research questions informed by uneven and combined Marxism: What hidden essential relations are now being exposed? What can be seen, talked about, abstracted, and theorized in this unusual period? What new tactics, alliances, organizational forms, and theoretical interventions can be built and imagined in such changing circumstances? These are vital questions for each county-based chapter in the Pennsylvania coalition, and they multiply manyfold at state and national scales. The virtual event is just one instance in the time of Covid-triggered capitalist crisis when essential relations among numerous, varied, and divided labors are on display. Ethnographic research directed to these questions and relations can, perhaps, better speak to our current situation and help amplify the conditions of possibility for counter-politics (Smith 2014.)

\section{References}

Bacon, David. May 18, 2020. Hundreds of Apple workers on strike in Washington. Labor Notes. https://www. labornotes.org/2020/05/hundreds-apple-workers-strike-washington, Accessed July 21, 2020.

Bond, Patrick, Ashwin Desai, and Trevor Ngwane. 2013. Uneven and combined Marxism within South Africa's urban social movements. In Marxism and social movements. Colin barker, ed. Laurence Cox, John Krinsky, and Alf Gunvald Nilsen, 233-258. Chicago: Haymarket.

Carbonella, August, and Sharryn Kasmir. 2014. Toward a global anthropology of labor. In Blood and Fire: Toward a Global Anthropology of Labor, ed. August Carbonella and Sharryn Kasmir, 1-29. New York: Berghahn Books.

Carbonella, August, and Sharryn Kasmir. 2015. Dispossession, disorganization and the anthropology of labor, in the anthropology of class. In , ed. Don Kalb and James Carrier, 41-53. Cambridge: Cambridge University Press.

Davidson, Neil. 2016. Uneven and combined development: modernity, modernism, revolution. In Historical sociology and world history: uneven and combined development over the longue duree, ed. Alexander Anievas and Kamran Matin, 31-53. New York: Rowan and Littlefield.

Dunn, Bill, and Hugo Radice, eds. 2006. 100 years of permanent revolution: results and prospects. London: Pluto.

Federici, Silvia. 2004. Caliban and the witch: Women, the body and primitive accumulation. New York: Autonomedia.

Gill, Lesley, and Sharryn Kasmir. 2016. History, politics, space, labor: on unevenness as an anthropological concept. Dialectical Anthropology 40 (2): 87-102.

Kalb, Don. 2018. Trotsky over Mauss: anthropological theory and the October 1917 commemoration. Dialectical Anthropology. 42 (3): 327-343.

Kalb, Don. (forthcoming 2020.) On the social relations of financialization in anthropology and history. In Financialization: Relational approaches. Chris Hann and Don Kalb, Eds. New York, Berghahn Press.

Kalb, Don, and Massimiliano Mollona. 2018. Introduction: introductory thoughts on anthropology and urban insurrections. In World wide mobilizations: class struggles and urban Commoning, ed. Don Kalb and Massimiliano Mollona, 1-31. Berghan: New York. 
Kasmir, Sharryn. 2020. The anthropology of labor. In Oxford Research Encyclopedia of Anthropology, ed. Mark Aldenderfer. New York: Oxford University Press.

Kasmir, Sharryn, and Lesley Gill. 2018. No smooth surfaces: an anthropology of unevenness and combination. Current Anthropology 59 (4): 355-377.

Lem, Winnie. 2016. The dialectics of uneven spatial-temporal development: migrants and reproduction in late capitalism. In Migration, temporality and capitalism: entangled mobilities across global spaces, ed. Pauline G. Barber and Winnie Lem. New York: Palgrave Macmillan.

Lem, Winnie. 2018. Comment. Current Anthropology. 59 (4): 569-570.

Makki, Fouad. 2015. Reframing development theory: the significance of the idea of uneven and combined development. Theory and Society 44 (5): 471-497.

Mullings, Leith. 1986. Uneven development: class, race and gender in the United States before 1900. In Women's work and the division of labor by gender, ed. Eleanor Leacock and Helen Safa, 41-57. South Hadley: Bergin \& Garvey.

Mullings, Leith. 1997. On our own terms: race, class and gender in the lives of African American women. New York: Routledge.

Peck, Jamie. 2019. Combination. Keywords in Radical Geography: Antipode at 50. https://onlinelibrary.wiley. com/doi/abs/10.1002/9781119558071.ch9, Accessed July 23, 2020.

Robinson, Cedric. 2000 (1983.) Black Marxism: the making of the black radical tradition. University of North Carolina Press.

Rodney, Walter. 1972. How Europe underdeveloped Africa. Washington, DC: Howard University Press.

Smith, Neil. 2006. The geography of uneven development. In 100 years of permanent revolution: results and prospects. Bill Dunn and Hugo Radice, eds. pp 180-195. London: Pluto.

Smith, Gavin. 2011. Selective hegemony and beyond-populations with "no productive functions": a framework for enquiry. Identities: Global Studies in Culture and Power 18 (1): 2-38.

Smith, Gavin. 2014. Intellectuals and (counter)politics. New York: Berghahn Books.

Smith, Gavin. 2016. Against social democratic angst about revolution: from failed citizens to critical praxis. Dialectical Anthropology 40: 221-239.

Smith, Gavin. 2020. The uneven and combined development of the agrarian question then and now. In The tumultuous politics of scale, ed. Ida Susser and Don Nonini. New York: Routledge.

Standing, Guy. 2011. The precariat: the new dangerous class. London: Bloomsbury Academic.

Trotsky, Leon. 1960 (1932.) Translated by Max Eastman. Peculiarities of Russia's development. The history of the Russian revolution, volume 1. Ann Arbor: University of Michigan Press.

Werner, Marion. 2016. Global displacements: the making of uneven development in the Caribbean. Malden: Wiley-Blackwell.

Publisher's note Springer Nature remains neutral with regard to jurisdictional claims in published maps and institutional affiliations. 